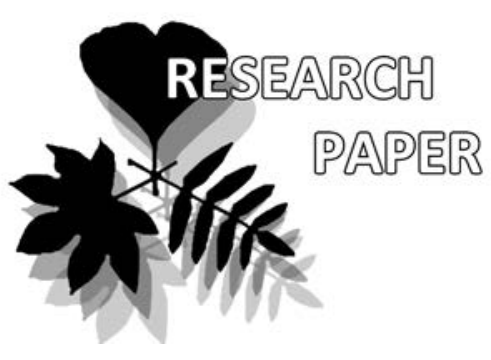

\title{
Phenolic compounds and antimicrobial properties of Begonia grandis Dryand. subsp. grandis leaves
}

Evgeniya A. Karpova ${ }^{1 *}$, Alexander A. Krasnikov ${ }^{1}$,

Tatyana D. Fershalova ${ }^{1}$, Elena V. Baikova ${ }^{1}$, Anastasia A. Petruk ${ }^{1}$ \&

Yulia L. Yakimova ${ }^{2}$

Evgeniya A. Karpova ${ }^{1 *}$

e-mail:karpova@csbg.nsc.ru

Alexander A. Krasnikov ${ }^{1}$

e-mail: tarax@mail.ru

Tatyana D. Fershalova ${ }^{1}$

e-mail: fershalova@ngs.ru

Elena V. Baikova ${ }^{1}$

e-mail: elenabaikova@mail.ru

Anastasia A. Petruk ${ }^{1}$

e-mail: pet.a@mail.ru

Yulia L. Yakimova ${ }^{2}$

e-mail: vladnyakimov@yandex.ru

${ }^{1}$ Central Siberian Botanical Garden

SB RAS, Novosibirsk, Russia

${ }^{2}$ State Research Center of Virology and Biotechnology VECTOR, Koltsovo, Russia

* corresponding author

Manuscript received: 03.04.2019

Review completed: 25.05.2019

Accepted for publication: 30.05.2019

Published online: 31.05.2019

\begin{abstract}
A B S T R A C T
We studied the leaves of Begonia grandis Dryand. subsp. grandis, the northernmost and most cold-resistant representative of the predominantly tropical genus Begonia, by histochemical methods. In glandular and nonglandular trichomes as well as in the epidermal cells of B. grandis Dryand. subsp. grandis leaves, phenolic compounds, including flavonoids, as well as terpenoids and carbonyl compounds were detected. The patterns of phenolic compounds in the acetone and ethanol leaf exudates and in leaves as a whole were similar and contained oxalic, citric, and gallic acids, isoquercitrin, and orientin. Concentrations of phenolic compounds in the acetone and ethanol exudates constituted $0.10 \%$ and $2.59 \%$ of all phenolic compounds in the leaves, respectively. Antimicrobial effects of the aqueous ethanol extract and of the ethanol exudate against reference strains of Bacillus subtilis, Staphylococcus aureus, and Candida albicans were detected at the disc contents of 50.0 and $45.8 \mu \mathrm{g}$, respectively. The observed set of characteristics can be used in a targeted search for highly antimicrobial species of Begoniaceae. K e y w o r d s : Begonia grandis subsp. grandis, flavonoids, orientin, oxalic acid, antimicrobial activity, leaf exudate, trichomes
\end{abstract}

\section{P E 3 Ю M E}

Карпова Е.А., Красников А.А., Фершахова Т.А., Байкова Е.В., Петрук А.А., Якимова Ю.А. Фенольные соединения и антимикробные свойства мистьев Begonia grandis Dryand. subsp. grandis. С помощью гистохимических методов исследованы мистья Begonia grandis Dryand. subsp. grandis - самого северного и холодоустойчивого преАставителя преимущественно тропического рода Begonia. В железистых и нежелезистых трихомах, а также в эпидермальных клетках мистьев выявлены фенольные соединения, в том числе флавоноиды, а также терпеноиды и карбонильные соединения. Фенольные соединения в ацетоновом и этанольном экссудатах Аистьев, а также Аистьях в целом имеют сходный состав, содержащий щавелевую, Аимонную и галцовую кислоты, изокверцитрин и ориентин. Концентрации

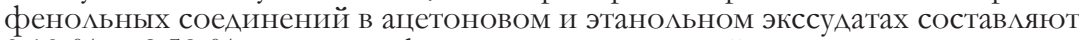
$0,10 \%$ и $2,59 \%$ от суммы фенольных соединений Аистьев, соответственно. Выявлено антимикробное Аействие водно-спиртового экстракта и этанольного экссудата на тестовые штаммы Bacillus subtilis, Staphylococcus aureus и Candida albicans при содержании 50,0 мкг и 45,8 мкг на Аиск, соответственно. Изученная система признаков может быть использована Аля направленного поиска видов Begoniaceae с высокой антимикробной активностью.

КАючевые слова: Begonia grandis subsp. grandis, флавоноиды, ориентин, щавелевая кислота, антимикробная активность, экссудат Аистьев, трихомы
Begonia grandis Dryand. [Begoniaceae Agardh., sect. Diploclinium (Lindl.) DC.] is a unique representative of the genus Begonia. This species is the northernmost, most cold-resistant taxon in Begoniaceae with one of the widest distributions in this family: its distribution longitude ranges from $97^{\circ} 27^{\prime} 34^{\prime \prime} \mathrm{E}$ to $121^{\circ} 47^{\prime} 15^{\prime \prime} \mathrm{E}$, and the latitude from $22^{\circ} 59^{\prime} 19^{\prime \prime} \mathrm{N}$ to $40^{\circ} 40^{\prime} 05^{\prime \prime} \mathrm{N}$ (Li et al. 2014). The wild plants of B. grandis inhabit sub-boreal summer green forests (Gu et al. 2007), unlike most representatives of the genus, which grow in tropical and subtropical regions. Therefore, within the temperate zone, plants of this taxon can vegetate in summer not only in a greenhouse but also in the open ground, surviving cooling to $+5^{\circ} \mathrm{C}$ without much damage to the aboveground part (Karpova \& Fershalova 2016). Its tuber can withstand freezing down to $-20^{\circ} \mathrm{C}$ ( $\mathrm{Li}$ et al. 2014).

Knowledge about protective compounds and their location in important for understanding of an adaptation mechanism. Phenolic compounds form the basis of plant protection against adverse environmental factors (ChalkerScott \& Fuchigami 1989). Various structural types of phenolic compounds exert distinct protective effects in the systems of plant interaction with the environment (plant - solar radiation, plant - soil, plant - air, plant - microorganisms, and plant - insects) (Cheynier et al. 2013, Kant et al. 2015). Some proportion of phenolic compounds in the leaves is located on their surface (Valant-Vetschera \& Brem 2006). 
These are exudate compounds, which most likely perform a specific function in the adaptation.

Flavonoids are the biggest class of phenolics with different structures and functions in plants (Andersen \& Markham 2006). We previously showed that anthocyanins and flavonols are useful for adaptation B. grandis subsp. grandis to a low temperature (Karpova et al. 2016, Karpova \& Fershalova 2016), but it is unclear how these compounds exert their activity. What part of the total phenolic content is on the surface of the leaf? What are these compounds, and in what secretory structures are they located? Localization of exudate compounds on the leaf surface is only the beginning of this kind of research. Phenolic compounds are reported to be present in secretory structures called trichomes (Combrinck et al. 2007, Kang et al. 2010).

Trichomes and exudate compounds in the extensive family Begoniaceae are poorly studied, despite the growing interest in them as a good source of biologically active compounds (Li et al. 2014). Secretion of bioactive compounds and their tissue distribution in B. grandis subsp. grandis leaves have not been examined.

The profile of exudate compounds was studied in detail in representatives of a few families including Asteraceae (Wollenweber et al. 1995, Valant-Vetschera et al. 2003a, Wollenweber et al. 2005a, Valant-Vetschera \& Wollenweber 2007, Muravnik et al. 2016), Betulaceae (Valkama et al. 2003), Boraginaceae (Wollenweber et al. 2002), Empetraceae (Muravnik \& Shavarda 2012), Lamiaceae (Valant-Vetschera et al. 2003b), Salicaceae (English et al. 1992, Greenaway et al. 1992 a,b), Oleaceae (Tattini et al. 2000), Scrophulariaceae, Ranunculaceae (Nikolova et al. 2003, Nikolova \& Asenov 2006), Rubiaceae (Muravnik et al. 2014), and Solanaceae (Wollenweber 2005b). Among these, mainly aglycones of flavones, flavonols, and flavanones and their hydroxy derivatives and methyl ethers were found. Catechins, hydroxycinnamic acids, and their derivatives, glycosides of flavonoids were also identified. Nevertheless, reports on the quantification of exudate compounds are still few (Tatini et al. 2000, Valkama et al. 2004, Muravnik \& Shavarda 2011, 2012).

The influence of solvents and extraction conditions on the completeness of extraction and the pattern of exudate compounds are not well studied. Different solvents are used for the extraction of exudate compounds by many researchers. Wollenweber et al. (1995, 2002, 2005a,b) performed the extraction of exudate compounds from representatives of Asteraceae, Boraginaceae, and Solanaceae with acetone; Muravnik investigated compounds of Asteraceae, Rubiaceae, and Empetraceae in methanol extracts (Muravnik \& Shavarda 2011, 2012, Muravnik et al. 2014, 2016). Valkama et al. (2003) and Tattini et al. (2000) extracted the exudates of Betulaceae and Oleaceae with ethanol. Greenaway (1992a) examined the exudates of buds and leaves of the genus Populus in ethyl acetate, and Heinrich et al. (2002) studied the exudates of Sigesbeckia jorullensis (Asteraceae) in chloroform. Lahtinen et al. (2006) demonstrated greater efficiency of $95 \%$ ethanol for the extraction of birch leaf surface flavonoids, in comparison with $70 \%$ acetone, $100 \%$ acetone, ethyl acetate, dichloromethane, or chloroform.

The time of extraction is in the range from several seconds (Tattini et al. 2000, Heinrich et al. 2002, Valkama et al. 2003) to several minutes (Nikolova et al. 2003). In many reports, the expressions "briefly rinsed" or "very briefly rinsed" are present (Wollenweber et al. 1995, Valant-Vetschera et al. 2003a, Valant-Vetschera \& Wollenweber 2007). The scope of reports on exudate-derived compounds of the leaves does not correspond to the great taxonomic diversity of plants.

The dominant phenolic constituent in the leaves of B. grandis subsp. grandis is C-glycosylflavone orientin (luteolin 8-C-glucoside). Leaves also contain several flavonol O-glycosides (hyperoside, isoquercitrin, and astragalin) and free aglycones (quercetin and luteolin), which make a significant contribution to adaptation to cold (Karpova et al., 2016).

The aims of the present study are to characterize the exudate compounds and their localization in the B. grandis subsp. grandis leaves and to examine the activities of the leaf extracts and exudates against some human pathogenic microorganisms.

\section{MATERIAL AND METHODS Analytical reagents}

All the chemicals were of analytical grade. These included the following: methanol from Panreac AppliChem (Barcelona, Spain), ortho-phosphoric acid from Sigma (St. Louis, MO, USA), chemical reference standards of gallic and ferulic acids from Serva (Heidelberg, Germany), oxalic acid, citric acid, L-ascorbic acid, quercetin, kaempferol, luteolin, orientin, isovitexin, astragalin, isoquercitrin, and kaempferol 3-O-rutinoside from Sigma, hyperoside from Fluka (Sigma-Aldrich Chemie GmbH, Munich, Germany). Mueller-Hinton agar and mycobiotic agar were acquired from Laboratorios Conda, S.A. (Madrid, Spain).

\section{Plant materials}

We grew B. grandis subsp. grandis plants in a greenhouse of the Central Siberian Botanical Garden (CSBG SB RAS), Novosibirsk, Russian Federation ("Collections of living plants indoors and outdoors" USU 440534): temperature varied from $+15^{\circ} \mathrm{C}$ up to $+30^{\circ} \mathrm{C}$, humidity was $40-60 \%$, and illumination 2000-5000 lx. We collected the samples of B. grandis subsp. grandis leaves in the period of active growth three times during June-July at an interval of 2 weeks.

For analysis of total phenolics in the leaves, we ground fresh leaves into a pulp using a household mill. Precisely weighed samples of fresh plant material $(0.5 \mathrm{~g})$ were exhaustively extracted with an ethanol:water mixture $(70: 30, \mathrm{v} / \mathrm{v})$ in a water bath at $60-70^{\circ} \mathrm{C}$ for $1.0-1.5 \mathrm{~h}$. Aqueous ethanol extract was filtered, diluted with the ethanol:water mixture (70:30, v/v) up to the volume of $25 \mathrm{ml}$ in a graduated flask, and subjected to the quantification of phenolic compounds. Dry-weight concentration in the samples was calculated by the gravimetric method.

For identification of exudate compounds, acetone and ethanol extracts of leaf surface constituents (exudates) were prepared. For acetone extraction, fresh (not ground) precisely weighed leaves were briefly rinsed (30-40 s) with acetone to dissolve the surface constituents. The ethanol extraction was performed with an analogous wash of fresh leaves with $95 \%$ ethanol. The acetone and ethanol solutions 
were evaporated to dryness, and each residue was dissolved in $1 \mathrm{ml}$ of $95 \%$ ethanol. These extracts of exudate constituents [acetone (A) and ethanol (E) exudates] were used for quantification.

\section{Scanning electron microscopy, fluorescence microscopy, and histochemistry}

Fresh leaves and leaf cross-sections were subjected to microscopy. Scanning electron microscopy was performed by means of a Hitachi TM-1000 tabletop scanning electron microscope (Hitachi High-Technologies Corporation, Japan) with original software. For preparation of cross-sections, plant material was transversely sectioned on a sledge microtome. Fresh leaves and anatomical sections were studied under a light microscope, Primo Star iLED (Carl Zeiss Microscopy GmbH, Germany), with a $470 \mathrm{~nm}$ light-emitting diode and filter set 09, a high-resolution 5-megapixel microscope camera (AxioCamMRc), and imaging software AxioVision 4.8 (Carl Zeiss Microscopy GmbH).

Localization of phenolic compounds was investigated by a 5 min histochemical test with $0.05 \%$ Toluidine Blue 0 in water (Muravnik et al. 2016).

The presence of terpenoids was demonstrated using the Nadi reagent. It was prepared immediately before use, by mixing $0.5 \mathrm{ml}$ of a $1 \% \alpha$-naphthol solution in $40 \%$ ethanol with $0.5 \mathrm{ml}$ of $1 \%$ dimethyl-p-phenylenediamine chloride in water and with $49 \mathrm{ml}$ of $0.05 \mathrm{M}$ phosphate buffer (pH 7.2) (David \& Carde 1964).

Carbonyl compounds were detected with 2,4-dinitrophenylhydrazine (Ganter \& Jollés 1969).

For fluorescence microscopy, fresh sections were stained with the Wilson reagent $[5 \%$ citric acid $(\mathrm{w} / \mathrm{v})$ and $5 \%$ boric acid (w/v) in absolute methanol] for $15 \mathrm{~min}$ (Muravnik et al. 2016) to detect flavonoids by inducing yellow-green fluorescence at $470 \mathrm{~nm}$. For all tests, standard control procedures were carried out simultaneously by the same methods.

\section{High-performance liquid chromatography (HPLC) analysis}

The HPLC system for absolute quantification of phenolics consisted of an Agilent 1200 with a diode array detector (DAD) and the ChemStation software (Agilent Technologies, USA) for data processing. The chromatographic separation was conducted at $25^{\circ} \mathrm{C}$ on a Zorbax SB-C18 Column $(4.6 \times 150 \mathrm{~mm}, 5 \mu \mathrm{m}$ internal diameter $)$ with the Agilent Guard Column Hardware Kit (p.n. 820888-901).

The mobile phase consisted of $\mathrm{MeOH}$ (solvent A) and $0.1 \%$ orthophosphoric acid in water (solvent B). Separation of glycosides and other derivatives of phenolic acids and flavonoids in the aqueous ethanol extract and exudates was performed with gradient I. The run via this gradient was started with a solvent A-solvent B mixture at 32:68 (v/v) followed by a linear gradient to $33: 67(\mathrm{v} / \mathrm{v})$ for the first $27 \mathrm{~min}$, then to $46: 64(\mathrm{v} / \mathrm{v})$ from minute 28 to minute 38 , next to $56: 44$ from minute 39 to minute 50 , and then to 100:0 from minute 51 to minute 54 . The mobile phase was returned to $32: 68(\mathrm{v} / \mathrm{v})$ from minute 55 to minute 56 . The flow rate was set to $1 \mathrm{ml} \cdot \mathrm{min}^{-1}$. The sample injection volume was $10 \mu \mathrm{l}$, and the absorbance was measured at 210, $255,270,290,325,340,360$, and $370 \mathrm{~nm}$.
Separation of organic and phenolic acids was carried out with gradient II. The run was started with a solvent A-solvent $B$ mixture at 17:83 (v/v) followed by a linear gradient to $70: 30(\mathrm{v} / \mathrm{v})$ for the first $30 \mathrm{~min}$, then to 100:0 from minute 31 to minute 32 . The mobile phase was returned to 22:78 (v/v) from minute 33 to minute 36 (Voronkova et al. 2016).

The quantification of phenolic compounds was conducted by the external-standard method. Validation of the analytical procedures was performed in accordance with ICH guidelines (2005). Standard stock solutions at a concentration of $1 \mathrm{mg} \cdot \mathrm{ml}^{-1}$ in methanol were used for building calibration curves in the concentration range of $2-100 \mu \mathrm{g} \cdot \mathrm{ml}^{-1}$. The sum of organic acids was calculated at $220 \mathrm{~nm}$, with citric acid as an external standard.

\section{Evaluation of antimicrobial activities}

The disk diffusion method was chosen for assaying the antimicrobial activities of the aqueous ethanol extract and exudates of B. grandis subsp. grandis leaves (EUCAST 2017). Strains from the American Type Culture Collection - Escherichia coli ATCC 25922, Pseudomonas aeruginosa ATCC 27853, Staphylococcus aureus ATCC 25923, Bacillus subtilis ATCC 6633, and Candida albicans ATCC 10231 - and a strain from the National Collection of Type Cultures (London), Alcaligenes faecalis NCTC 415, were employed as reference strains. Ciprofloxacin $(5 \mu \mathrm{g})$ served as a standard antibacterial agent, and itraconazole $(10 \mu \mathrm{g})$ as a standard antifungal agent (positive control). Ethanol served as a negative control.

\section{Statistical analysis}

All the data were processed in the Statistica 10.0 software (Statsoft Inc., Tulsa, OK, USA), were reported as mean \pm standard deviation (SD) of three replicates, and were compared by the nonparametric Mann-Whitney U test. Differences between the means were considered statistically significant at the $5 \%$ level $(\mathrm{p}<0.05)$.

\section{RESULTS}

\section{Location of phenolic compounds}

We detected two types of trichomes on the leaf surfaces of $B$. grandis subsp. grandis. The first ones are large conical hairs, which we identified as multicellular multiserial nonbranching trichomes or emergences. On the adaxial leaf surface, they were longer $(660 \pm 31 \mu \mathrm{m})$ than on the abaxial surface (401 $\pm 34 \mu \mathrm{m}$; Fig. 1a). They are located mainly along the veins on the abaxial side of the leaf and at the leaf margins and scarcely on the adaxial side. Similar conical multicellular trichomes in B. grandis and other Chinese begonias were described by Shui et al. (1999, 2002).

Trichomes of another type were located on both surfaces of the leaf. These are small capitate glandular trichomes represented by an oblong head $(25 \pm 4 \mu \mathrm{m}$ in diameter and $37 \pm 5 \mu \mathrm{m}$ in length) and a stalk ( $30 \pm 2 \mu \mathrm{m}$ long; Fig. $1 \mathrm{~b})$. The head is formed by $7-15$ cells. The stalk is uniserial and consists of 4 cells and a single basal cell. On the developed leaf, the hairs of both types are distributed evenly (Fig. 1a).

We found salt deposits on the adaxial and abaxial leaf surfaces (Fig. 2a) and on the surface of nonglandular trichomes (Fig. 2b). 


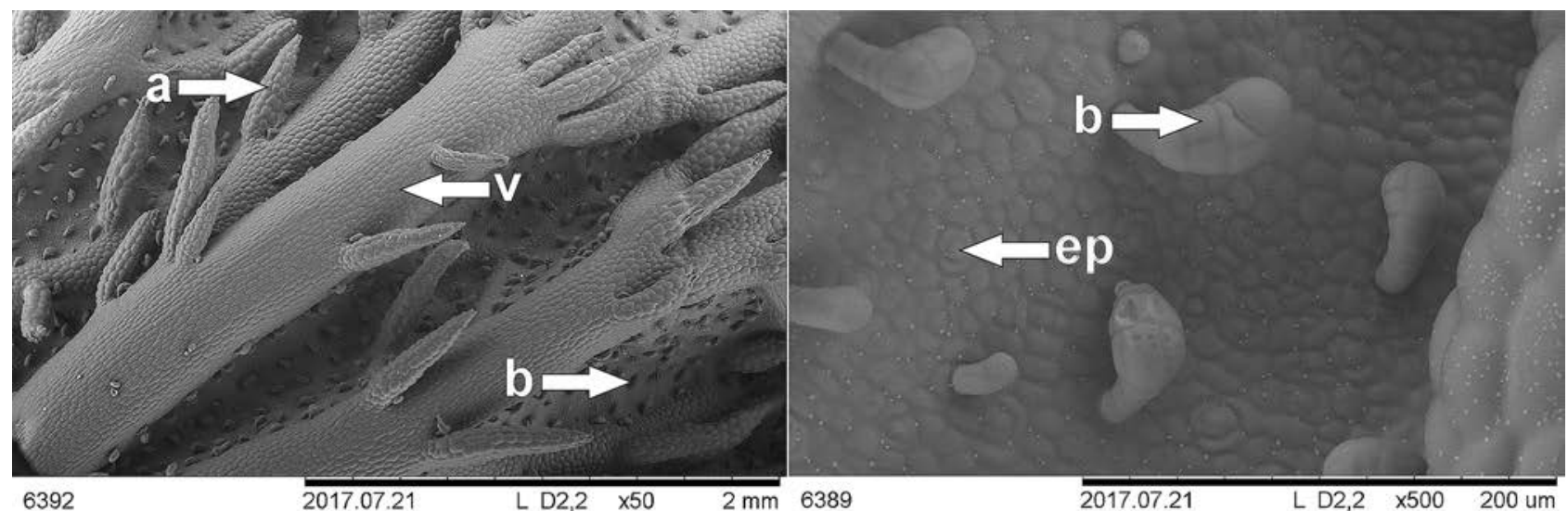

Figure 1 Trichomes on the leaves of B. grandis subsp. grandis, abaxial leaf surface: a - nonglandular trichomes; b - capitate glandular trichome; ep - epidermis; $\mathrm{v}$ - veins
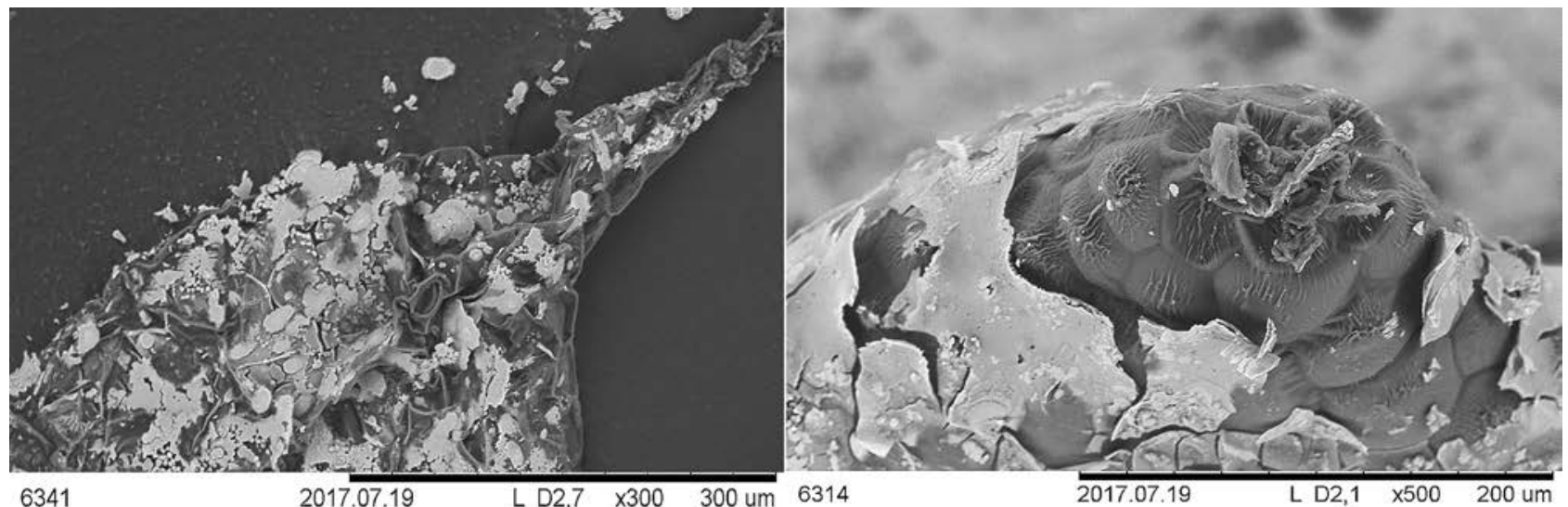

Figure 2 Leaf section (left) and a tip of a nonglandular trichome (right) on the leaf of B. grandis subsp. grandis with a salt deposit

Secretions in most of glandular trichomes were clearly visible (Fig. 3a). Capitate glandular trichomes stained intensely blue with Toluidine Blue (Fig. 3c). Nonglandular trichomes stained much more weakly, and the color distribution was uneven (Fig. 3d). Tests for terpenoids and carbonyl compounds yielded positive results in both types of hairs (Fig. 3f, g, i, j). The purple color after Nadi staining indicates the presence of oil resin, and violet staining of the cells of the adaxial epidermis pointed to the presence of monoterpenes (Fig. 3h) (Pinheiro et al. 2018). The presence of phenolic compounds in cells walls within the abaxial epidermis was identified by areas of a blue color after Toluidine Blue staining (Fig. 3e). Carbonyl compounds in the wall of the adaxial epidermis cells were revealed by a red color after 2,4-dinitrophenylhydrazine staining (Fig. 3k).

\section{HPLC analysis}

The fluorescence of flavonoids from the glandular and nonglandular trichomes on the leaf surface indicated the presence of these compounds in the exudate. Hence, we assessed separately the concentration of the compounds in the leaves $(\mathrm{L})$ and the concentration of compounds in the leaf surface exudate. We detected the exudate compounds via two modifications of the extraction procedure, namely, with two different solvents most commonly used in the research on surface compounds: acetone (A) and ethanol (E).
In the leaves as a whole, we detected phenolic acids (including gallic and ferulic acids), C-glycosylflavone (orientin and isovitexin), flavonol O-glycosides (including hyperoside, isoquercitrin, astragalin, and kaempferol 3-O-rutinoside), free quercetin and luteolin, and a few unidentified flavonol glycosides. Most of these constituents were found in the exudates too (Table 1). Concentrations of total flavonoids and total phenolic compounds in the leaf tissues were 7.0 and $20.9 \mathrm{mg} / \mathrm{g}$, respectively.

The main phenolic constituents of the leaves were found to be gallic acid, orientin, and isoquercitrin. The leaves also showed a high concentration of total organic acids and a certain amount of free aglycones, quercetin, and luteolin.

Total concentration of organic constituents extracted with ethanol (E) exceeded that extracted with acetone (A) more than 20-fold; these fractions represented 2.59 and $0.10 \%$ of total phenolic compounds in leaves, respectively. Each compound's proportion in the exudate (relative to the total concentration in the leaves) ranged from $0.03 \%$ (hyperoside, isoquercitrin) to $0.33 \%$ (astragalin), and from $0.61 \%$ (hyperoside) to $6.53 \%$ (the sum of organic acids) in the experiments on extraction with acetone and ethanol, respectively. Orientin and organic acids were the main organic constituents of the exudate after extraction with either solvent. Among the exudate compounds extracted with acetone, quercetin was present only in minute amounts 
Table 1. Total concentrations of phenolic compounds $\left(\mu \mathrm{g}^{\cdot} \mathrm{g}^{-1}\right.$ of dry weight) in the leaves $(\mathrm{L})$ and their concentrations on the leaf surface of B. grandis subsp. grandis after extraction of exudate compounds with acetone (A) or ethanol (E)

\begin{tabular}{|c|c|c|c|c|c|c|c|}
\hline \multirow[t]{2}{*}{ Compound } & \multirow[t]{2}{*}{$T_{R}(\min )$} & \multirow[t]{2}{*}{$\lambda \max , \mathrm{nm}$} & \multirow[t]{2}{*}{$\mathbf{L}$} & \multicolumn{2}{|l|}{ A } & \multicolumn{2}{|l|}{$\mathbf{E}$} \\
\hline & & & & $\bar{A}$ & $A / L, \%$ & $E$ & $E / L, \%$ \\
\hline Sum of organic acids & 1.5 & 250 & $1883.9 \pm 42.2$ & $4.2 \pm 0.6$ & $0.22 \pm 0.03$ & $123.1 \pm 13.8$ & $6.53 \pm 0.59$ \\
\hline Gallic acid & 1.7 & 270 & $2252.6 \pm 80.6$ & $1.9 \pm 0.5$ & $0.08 \pm 0.02$ & $26.7 \pm 5.1$ & $1.19 \pm 0.27$ \\
\hline Orientin & 8.8 & $254,268,350$ & $3520.7 \pm 242.0$ & $5.2 \pm 0.5$ & $0.15 \pm 0.02$ & $133.7 \pm 1.7$ & $3.80 \pm 0.27$ \\
\hline Flavonol glycoside $13 *$ & 11.3 & 250,350 & $928.8 \pm 5.9$ & $1.1 \pm 0.3$ & $0.12 \pm 0.03$ & $56.5 \pm 3.6$ & $6.08 \pm 0.36$ \\
\hline Flavonol glycoside $14^{*}$ & 14.7 & 250,350 & $1654.1 \pm 30.9$ & $0.7 \pm 0.2$ & $0.04 \pm 0.02$ & $25.8 \pm 3.0$ & $1.56 \pm 0.17$ \\
\hline Isovitexin & 16.2 & 274,329 & $376.3 \pm 15.7$ & $0.3 \pm 0.2$ & $0.08 \pm 0.04$ & $9.2 \pm 0.9$ & $2.44 \pm 0.33$ \\
\hline Hyperoside & 18.3 & 255,355 & $293.7 \pm 19.6$ & $0.1 \pm 0.0$ & $0.03 \pm 0.01$ & $1.8 \pm 0.5$ & $0.61 \pm 0.17$ \\
\hline Isoquercitrin & 19.0 & 255,355 & $2146.7 \pm 23.3$ & $0.6 \pm 0.3$ & $0.03 \pm 0.01$ & $21.8 \pm 2.5$ & $1.02 \pm 0.12$ \\
\hline Astragalin & 32.2 & 265,346 & $182.0 \pm 7.7$ & $0.6 \pm 0.2$ & $0.33 \pm 0.13$ & $3.1 \pm 0.5$ & $1.73 \pm 0.32$ \\
\hline Kaempferol 3-O- rutinoside & 33.4 & 265,348 & $264.9 \pm 13.8$ & $0.21 \pm 0.1$ & $0.08 \pm 0.04$ & $\mathrm{Nd}$ & 0.00 \\
\hline Quercetin & 40.2 & 260,370 & $105.6 \pm 3.1$ & $0.1 \pm 0.0$ & $0.09 \pm 0.05$ & $\mathrm{Nd}$ & 0.00 \\
\hline Luteolin & 44.1 & $255,267,350$ & $54.6 \pm 2.7$ & $\mathrm{Nd}$ & 0.00 & $\mathrm{Nd}$ & 0.00 \\
\hline Sum of the compounds & & & $13663.9 \pm 487.5$ & $15.0 \pm 1.1$ & $0.11 \pm 0.01$ & $401.8 \pm 9.1$ & $2.94 \pm 0.11$ \\
\hline Total flavonoids & & & $7013.4 \pm 265.6$ & $8.8 \pm 0.81$ & $0.13 \pm 0.02$ & $258.3 \pm 8.1$ & $3.68 \pm 0.03$ \\
\hline Total phenolic compounds & & & $20861.9 \pm 423.1$ & $21.0 \pm 1.1$ & $0.10 \pm 0.01$ & $540.6 \pm 5.7$ & $2.59 \pm 0.06$ \\
\hline
\end{tabular}

* Concentration as citric acid equivalents; ** Concentration as hyperoside equivalents; Nd: not detectable.

Table 2. The concentrations of organic acids $\left(\mathrm{mg} \cdot \mathrm{g}^{-1}\right.$ of dry weight) in the leaves of $B$. grandis subsp. grandis

\begin{tabular}{llll}
\hline Compound & $\mathbf{T}_{\mathbf{R}}(\min )$ & $\lambda$ max, $\mathbf{n m}$ & Concentration \\
\hline Oxalic acid & 1.44 (II*) & 220 & $0.7 \pm 0.1$ \\
Ascorbic acid & 1.56 (II) & 250 & $0.2 \pm 0.0$ \\
Citric acid & 1.95 (II) & 220 & $1.0 \pm 0.2$ \\
Sum of organic acids & 1.50 (I) & 220 & $1.9 \pm 0.0$ \\
\hline
\end{tabular}

* gradient number.

Table 3. Concentrations of phenolic compounds $\left(\mu \mathrm{g} \cdot \mathrm{ml}^{-1}\right)$ in the aqueous ethanol extract of the leaves (L) and in the leaf exudates of B. grandis subsp. grandis extracted with acetone (A) or ethanol (E)

\begin{tabular}{llll}
\hline Compound & L & A & E \\
\hline Sum of organic acids* & $4.1 \pm 0.3$ & $5.5 \pm 0.4$ & $22.3 \pm 2.3$ \\
Gallic acid & $5.2 \pm 0.4$ & $2.6 \pm 0.2$ & $4.2 \pm 0.4$ \\
Orientin & $7.4 \pm 0.6$ & $7.3 \pm 0.5$ & $20.0 \pm 1.7$ \\
Flavonol glycoside 13** & $1.9 \pm 0.2$ & $1.4 \pm 0.1$ & $8.2 \pm 0.6$ \\
Flavonol glycoside $14 * *$ & $3.0 \pm 0.2$ & $0.8 \pm 0.1$ & $2.5 \pm 0.2$ \\
Isovitexin & $0.8 \pm 0.1$ & $0.3 \pm 0.0$ & $1.5 \pm 0.2$ \\
Hyperoside & $0.5 \pm 0.0$ & $0.1 \pm 0.0$ & $0.3 \pm 0.0$ \\
Isoquercitrin & $5.2 \pm 0.4$ & $0.8 \pm 0.1$ & $3.2 \pm 0.2$ \\
Astragalin & $0.5 \pm 0.0$ & $0.8 \pm 0.1$ & $0.7 \pm 0.1$ \\
Kaempferol 3-O-rutinoside & $0.7 \pm 0.0$ & $0.3 \pm 0.0$ & $\mathrm{Nd}$ \\
Quercetin & $0.2 \pm 0.0$ & $0.05 \pm 0.00 \mathrm{Nd}$ \\
Luteolin & $0.1 \pm 0.0$ & $\mathrm{Nd}$ & $\mathrm{Nd}$ \\
\hline Sum of the compounds & $29.6 \pm 2.2$ & $19.9 \pm 1.4$ & $62.9 \pm 5.5$ \\
\hline Total flavonoids & $23.9 \pm 1.7$ & $14.5 \pm 1.0$ & $40.9 \pm 4.1$ \\
\hline Total phenolic compounds 45.7 \pm 3.3 & $28.1 \pm 2.1$ & $144.8 \pm 10.5$ \\
\hline * Concentration as citric acid equivalents, **concentration
\end{tabular}

and was not detected at all in the experiment with extraction via ethanol. Luteolin was not detected among exudate compounds after extraction with either solvent. Consequently, the ethanol exudate in contrast to the acetone exudate did not contain free aglycones.

In the experiment with acetone extraction, the concentrations of total exudate flavonoids and total exudate phenolic compounds in the fraction of total leaf phenolics were essentially the same. This finding indicates equal extractability of flavonols and other phenolics from the leaf surface by acetone. In contrast, from the leaf surface, flavonoids were extracted in greater amounts by ethanol in comparison with other phenolics.

Concentrations of total organic acids and orientin in the fraction of total phenolic compounds from the leaf surface were higher in comparison with the leaf as a whole. Such concentrations of quercetin differed slightly, and these concentrations of isoquercitrin and gallic acid were substantially lower in the surface fraction. Concentrations of total flavonoids were higher in the fraction of total phenolic compounds from the leaf surface than in the leaf as a whole; in the experiment with ethanol extraction, they were higher than in the experiment with acetone extraction.

In the fraction of total organic acids from the leaves, we detected oxalic, ascorbic, and citric acid (Table 2).

Concentrations of oxalic and citric acid in the leaves were significantly higher in comparison with the ascorbic acid concentration.

\section{Antimicrobial activity}

We examined antimicrobial properties of B. grandis in the aqueous ethanol extract of the leaves (L) and in the acetone (exudates A) and ethanol (exudates E) exudates from the leaves of B. grandis subsp. grandis. To assess the impact of concentrations of the constituents on antimicrobial properties of the extract and exudates, we calculated the concentrations of the compounds in them (Table 3).

Phenolic composition was similar between the extract and exudates, but there were slight differences. The sum of phenolic compounds was the greatest in exudate E $\left(144.8 \mu \mathrm{g} \cdot \mathrm{ml}^{-1}\right)$ and was the smallest in exudate A $\left(28.1 \mu \mathrm{g} \cdot \mathrm{ml}^{-1}\right)$. We noted an analogous pattern for the concentrations of total flavonoids (40.9 and $14.5 \mu \mathrm{g} \cdot \mathrm{ml}^{-1}$, respectively). Exudate $\mathrm{E}$ was exceptional in the concentrations of orientin, total organic acids, flavonol glycoside 13, and isovitexin, whereas the aqueous ethanol extract surpassed the others in the concentrations of gallic acid, flavonol glycoside 14, hyperoside, isoquercitrin, kaempferol 3 -rutinoside, quercetin, and luteolin. 


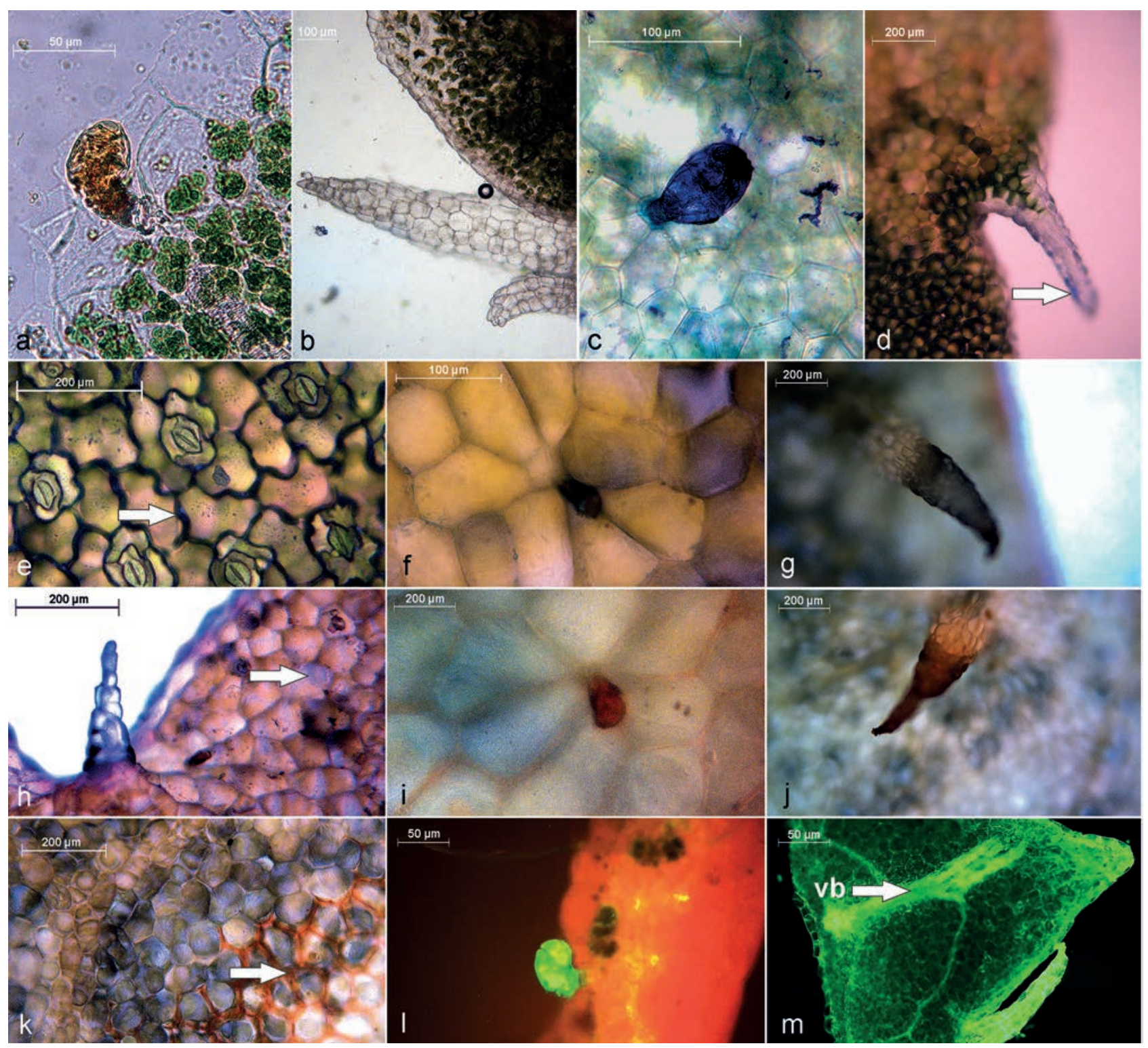

Figure 3 Histochemical visualization of phenolic compounds, flavonoids, and terpenoids in the leaves of B. grandis subsp. grandis. a, b: trichomes uncolored: a - capitate glandular trichome on the adaxial leaf surface with secretions, $\mathrm{b}$ - nonglandular trichome; $\mathrm{c}, \mathrm{f}, \mathrm{i}$, and l: glandular trichome; d, g, h, and j: nonglandular trichomes; c - e: blue color of the phenolic compounds stained with Toluidine Blue; d: irregular staining of nonglandular trichomes; e: staining of the cell walls within the abaxial epidermis; $\mathrm{f}-\mathrm{h}$ : terpenoids stained with Nadi; $\mathrm{f}$, g: dark purple staining of the trichomes; h: violet staining of the epidermal cells; i-k: carbonyl compounds stained with 2,4-dinitrophenylhydrazine; $i, j$ : reddish-brown staining of trichomes; $k$ : red staining of the cell walls within the adaxial epidermis; 1 , m: green fluorescence of flavonoids with the Wilson reagent $(470 \mathrm{~nm})$; $\mathrm{m}$ : fluorescence of the nonglandular trichome and a vascular bundle; the arrows indicate the places of concentration of the dye in the tissues; vb: vascular bundle

The spectra of antimicrobial activities in the extract and exudates of B. grandis subsp. grandis leaves were found to be different. Low levels of total phenolic compounds and flavonoids apparently were the reason for the absence of antimicrobial activities in the acetone exudate toward any reference strains. Nevertheless, the differences in the antimicrobial spectra did not exactly correspond to the differences in the total concentrations of phenolic compounds and flavonoids. Even though exudate E contained greater amounts of phenolic compounds and flavonoids than did the aqueous ethanol extract, a greater number (3 strains) of the reference strains were sensitive to the aqueous ethanol extract (Table 4) than to exudate E (2 strains).

None of the extracts of $B$. grandis subsp. grandis leaves showed activity against the reference strains of gram-nega- tive bacteria. Thus, antimicrobial effects of the extract and exudate $E$ against reference strains of $S$. aureus and $C$. albicans, and the action of the extract against $B$. subtilis were comparable with the activities of standard antimicrobial drugs. The amounts of the extract or of exudate $\mathrm{E}$ in the disk were 50.0 and $45.8 \mu \mathrm{g}$ of dry weight, respectively (corresponding to total phenolic concentrations of 0.5 and $1.4 \mu \mathrm{g}$ ).

\section{DISCUSSION}

Results of HPLC uncovered a high concentration of total phenolics in the leaves of B. grandis subsp. grandis (up

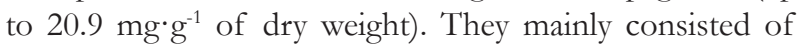
organic acids, gallic acid, and orientin. C-glycosylflavones currently are being detected in an increasing number of Begonia species (Joshi et al. 2015), and these compounds 
Table 4. Sensitivity (diameter of inhibition zone, $\mathrm{mm}$ ) of the reference strains of microorganisms to the aqueous ethanol extract and exudates of $B$. grandis subsp. grandis leaves

\begin{tabular}{|c|c|c|c|c|}
\hline Organism & Aqueous ethanol extract & Exudate A & Exudate E & Standard drug $^{a}$ \\
\hline $\begin{array}{l}\text { Gram-positive bacteria } \\
\text { Bacillus subtilis } \\
\text { Staphylococcus aureus }\end{array}$ & $\begin{array}{l}25.1 \pm 1.5 \\
24.8 \pm 0.9\end{array}$ & $\begin{array}{l}0.0 \pm 0.0 \\
0.0 \pm 0.0\end{array}$ & $\begin{array}{l}0.0 \pm 0.0 \\
25.6 \pm 1.7\end{array}$ & $\begin{array}{l}25.2 \pm 0.7 \\
23.1 \pm 1.5\end{array}$ \\
\hline $\begin{array}{l}\text { Gram-negative bacteria } \\
\text { Escherichia coli } \\
\text { Pseudomonas aeruginosa } \\
\text { Alcaligenes faecalis } \\
\text { Disk content ( } \mu \mathrm{g})\end{array}$ & $\begin{array}{l}0.0 \pm 0.0 \\
0.0 \pm 0.0 \\
0.0 \pm 0.0 \\
50.0\end{array}$ & $\begin{array}{l}0.0 \pm 0.0 \\
0.0 \pm 0.0 \\
0.0 \pm 0.0 \\
35.2\end{array}$ & $\begin{array}{l}0.0 \pm 0.0 \\
0.0 \pm 0.0 \\
0.0 \pm 0.0 \\
45.8\end{array}$ & $\begin{array}{l}29.7 \pm 1.3 \\
25.9 \pm 1.3 \\
21.4 \pm 1.3 \\
5.0\end{array}$ \\
\hline $\begin{array}{l}\text { Fungi } \\
\text { Candida albicans } \\
\text { Disk content ( } \mu \mathrm{g} \text { of dry matter) } \\
\text { Disk content ( } \mu \mathrm{g} \text { of phenolic compounds) }\end{array}$ & $\begin{array}{l}13.3 \pm 0.6 \\
50.0 \\
0.5 \pm 0.0\end{array}$ & $\begin{array}{l}0.0 \pm 0.0 \\
35.2 \\
0.3 \pm 0.0\end{array}$ & $\begin{array}{l}16.2 \pm 0.5 \\
45.8 \\
1.4 \pm 0.1\end{array}$ & $\begin{array}{l}15.9 \pm 1.4 \\
10.0 \\
10.0\end{array}$ \\
\hline
\end{tabular}

${ }^{a}$ Ciprofloxacin $(5 \mu \mathrm{g})$ against bacteria, itraconazole $(10 \mu \mathrm{g})$ against $C$. albicans

appear to be chemotaxonomic markers of this genus. Phenolic compounds of the leaf surface were found to be enriched with orientin and organic acids.

Even though the presence of crystals and druses of calcium oxalate is considered a taxonomic characteristic of the genus Begonia, and the genus belongs to the group of oxalicacid-accumulating plants (Villa-Ruano et al. 2017), there are no descriptions, images, or a good understanding of the location of salt druses or crystals in the cells and tissues. There are rare reports on the presence of cystolites in the epidermal cells of representatives of this genus (Pireyre 1961). Our scanning electron microscopy data revealed that the localization of salt deposits is on the leaf surface and on the surface of nonglandular trichomes. This finding is well consistent with the substantial amount of total organic acids, including oxalic acid. The profile of organic acids and the dynamics of their concentrations in the leaves and on the leaf surface will be a subject of our future study.

Histochemical staining indicated the presence of phenolic and carbonyl compounds, flavonoids, and terpenoids in both trichome types. Intensive fluorescence of nonglandular trichomes and vascular bundles with the Wilson reagent suggests that nonglandular trichomes are involved in the flavonoid transport inside the leaf to trichome cells, which is most likely carried out through the vascular bundles. The existence in plants of a long-range transport of flavonoids mediated by vascular bundles was inferred from the finding that physiological effects of flavonoids are manifested far from their synthesis site (Petrussa et al. 2013).

Our results showed that the majority of surface organic compounds of this plant are hydrophilic (phenolic acids and flavonol glycosides), and we can suppose that they likely derive from vacuoles of leaf tissues. These data are consistent with the report by Tattini et al. (2007) who detected two coumaroyl derivatives of kaempferol 3-O-glucoside (astragalin) in nonsecretory stellate and dendritic trichomes of Cistus salvifolius leaves. These acyl kaempferol glycosides were associated with the cell wall of trichome arms, which is an optimal location for an effective UV screen.

Nevertheless, information about the mechanisms of flavonoid transport across endomembranes and about subsequent accumulation in different compartments is still limited. Histochemical staining of vascular bundles in the leaves of B. grandis subsp. grandis confirmed the presence of flavonoid transport through the vascular system of this plant.

Phenolic compounds in the glandular trichomes most probably have another origin. Glandular trichomes have in common the capacity to produce, store, and secrete large amounts of different classes of secondary metabolites (Glas et al. 2012). They predominantly produce nonvolatile or poorly volatile compounds that are directly exuded onto the surface of the trichome (Tissier 2012). Constituents of glandular trichomes are mostly lipophilic (terpenes, lipids, waxes, and flavonoid aglycones); they are known to be synthesized inside the trichome and are transferred outside through the membrane systems of the cells (Valkama et al. 2003, Oteiza et al. 2005). In addition to free flavonoid aglycones (luteolin, quercetin, and kaempferol), lipophilic phenolic compounds include some phenolic acids. Certain lowmolecular-weight components, including some phenolic acids and their derivatives, have relatively high lipophilicity and may be capable of incorporation into the lipid layer (Chalas et al. 2001, Cilius et al. 2013). Terpenoids and phenolics secreted by glandular trichomes may provide chemical or physicochemical protection from herbivores and pathogens by entrapping or poisoning them (Wagner 1991).

Two independent ways of secretion of lipophilic and hydrophilic compounds are observed in many plants. For example, in the genus Nicotiana, accumulation of lipophilic constituents occurs in oblong trichomes, and accumulation of hydrophilic ones (including alkaloids) proceeds in short trichomes; these do not have intracellular structures for the synthesis. Thus, there is an assumption about the transport of these constituents from inside the leaf to trichomes on its surface (Meyberg et al. 1991). Wollenweber (2005b) made a conclusion about the secretion of aglycones and glycosides of flavonoids via different morphological types of trichomes.

Chemical traits of nonglandular trichomes are poorly studied at present. The majority of reports address only the glandular trichomes' morphology and histochemistry. Cover hairs of some taxa do not participate in secretion (Muravnik 2008), but others secrete essential oils and other lipophilic compounds (Pinheiro et al. 2018).

Thus, on the basis of our results and current literature data, we can assume that the quantitative ratio of flavonoid glycosides to aglycones generally corresponds to the ratio 
of surface areas of nonglandular and glandular trichomes. Low diversity and the restricted distribution of flavonoid aglycones in the leaves of B. grandis subsp. grandis are in sharp contrast to the great variety and abundance in the representatives of Asteraceae and Lamiaceae (Valant-Vetschera et al. 2003b, Wollenweber et al. 2005a). This abundance is in agreement with the diversity of glandular hairs in the plants of these taxa. They usually bear both peltate and capitate glandular hairs, or several types of capitate hairs, on the leaf surface (Werker et al. 1985), and the size and density are greater in comparison with nonglandular hairs (Heinrich et al. 2002). Accordingly, as in our study, substantial amounts of organic and phenolic acids were detected in the secretions of glandular hairs (Muravnik et al. 2016).

We believe that the predominance of nonglandular multicellular trichomes saturated with flavonoid glycosides as well as the abundance of flavonoid glycosides in the vein system of the B. grandis subsp. grandis leaf are suggestive of the high importance of protection against excessive solar radiation in this shade-tolerant plant growing under the forest canopy (Tattini et al. 2000). Nonglandular cover hairs play a role in light dissipation. The photoprotection by abaxial phenolic compounds, including anthocyanins, is essential for plants in which the exposed abaxial leaf surfaces are vulnerable to incident light during light-sensitive developmental stages (Hughes et al. 2014).

The results of histochemical staining with Toluidine Blue point to the presence of phenolic compounds also in the cell walls within the abaxial epidermis (Fig. 2e); these data match the reports on the presence and upregulation of cell wall phenolic compounds in various plant organs in response to pathogens (Nicholson \& Hammerschmidt 1992, Dai et al. 1996, McNally et al. 2003). Besides, there are reports on the contribution of phenolic compounds (and flavonoids located in the wall of epidermal cells) to UV protection (Jansen et al. 2001, Agati et al. 2007).

The photoprotective function of phenolic compounds and of flavonoids from the abaxial leaf surface is still debatable. For abaxial anthocyanins, their protection from UV light is assumed to be effective at low light intensities, providing photoprotection only when intensities are high enough to penetrate the mesophyll (Hughes et al. 2008). High concentrations of phenolic compounds in the cell walls within the abaxial epidermis and of flavonoids in nonglandular trichomes on the abaxial leaf surface show their importance for photoprotection of palisade layers, where the highest photosynthesis rates are found (Evans \& Vogelmann 2003, Soares et al. 2008).

Terpenes inside the epidermal cells and carbonyl compounds in the cell walls within the adaxial epidermis most likely are part of chemical defense mechanisms intended to repel or evade biotic attacks (Chehab et al. 2008). Furthermore, these biochemical and anatomical characteristics form the basis for the antimicrobial activities toward human pathogens (Dardick \& Ronald 2006).

We assumed that the low levels of phenolic compounds in the acetone exudate (and minute amounts of flavonoid aglycones in the extract and both exudates of B. grandis subsp. grandis leaves) probably are responsible for the absence of antimicrobial effects in the acetone exudate and for the relatively weak antimicrobial activities in the extract and ethanol exudates (against three among six reference strains, none of gram-negative strains). The growth-inhibitory effect evidently is due to constituents having substantial antimicrobial properties, such as gallic acid (Teodoro et al. 2015, Li et al. 2017), quercetin glycosides (Özçelik et al. 2006, Veras et al. 2011), and C-glycosylflavones (McNally et al. 2003).

Our results mean that acetone when used for the extraction of exudative constituents from the leaves of taxa with active secretion does not provide complete extraction of leaf surface constituents from Begoniaceae representatives. Phenolic constituents of the leaf surface of B. grandis subsp. grandis are extracted better with ethanol, as are leaf surface compounds of Betula (Valkama et al. 2003) and Pbillyrea (Tattini et al. 2000). The best solvent type and extraction conditions most likely depend on the structure of exudate compounds and taxonomic affiliation of the plant. Previously, we reported that flavonoids from the leaves of another species of Begonia, B. malabarica, are extracted better with acetone than with ethanol (Karpova et al. 2018).

These results together with the current data indicate that anatomical and histochemical characteristics of the leaf epidermis and trichomes, as well as the pattern of phenolic compounds in the leaves and their exudates, are prognostic factors and predictive signs of antimicrobial activity. They constitute a set of traits suited to the search for antimicrobial activity and will be a topic of our research in the future.

This study confirms successful application of intact plants and natural products from the leaves of B. grandis subsp. grandis for human health and indoor air cleaning ( $\mathrm{Li}$ et al. 2014, Hwang et al. 2015, Fershalova et al. 2018).

\section{CONCLUSION}

We determined the localization of phenolic compounds, including flavonoids, as well as terpenoids and carbonyl compounds in two types of trichomes on the leaf surface of B. grandis subsp. grandis (capitate glandular trichomes and conical multicellular nonglandular ones) by histochemical methods. We detected these bioactive compounds in epidermal cells too. The positive test results on flavonoids in the nonglandular trichomes and in vascular bundles by means of the Wilson reagent indicate their participation in the transport of flavonoids from an internal leaf structure to the leaf surface.

The profiles of phenolic compounds in the leaf exudates and leaves as a whole were similar and contained compounds with pronounced antimicrobial properties: phenolic acids (gallic and ferulic acids), C-glycosylflavones (orientin and isovitexin), and flavonol O-glycosides (hyperoside, isoquercitrin, astragalin, and kaempferol 3-O-rutinoside). On the other hand, their total fraction in the acetone exudates lacks an antimicrobial activity; this activity was revealed in the aqueous ethanol extract and the ethanol exudate (against reference strains of $S$. aureus, B. subtilis, and C. albicans). For the antimicrobial effect, most likely, a certain concentration of phenolic compounds (up to $46 \mu \mathrm{g} \cdot \mathrm{ml}^{-1}$ ) and flavonoids (up to $24 \mu \mathrm{g} \cdot \mathrm{ml}^{-1}$ ) is needed in the extract.

The presence of these constituents in B. grandis subsp. grandis leaves points to the health benefits of the natural 
products from these leaves. Nevertheless, their preparation should be accompanied by the monitoring of oxalic acid levels. Examination of the dynamics of its quantities in the leaves is essential for the production of natural products. Localization of a considerable proportion of organic acids on the leaf surface enables their removal from the leaves without complex processing. The type of solvent is one of the main factors for effective extraction of surface exudate constituents.

Rich phenolic content of the leaves and leaf exudates of B. grandis subsp. grandis opens up new opportunities for novel technologies of indoor air cleaning.

We propose this set of histochemical and phenolic-composition characteristics for further research into the antimicrobial activities of the representatives of Begoniaceae.

\section{ACKNOWLEDGEMENTS}

The work was carried out as part of the state assignment of the Central Siberian Botanical Garden of the SB RAS with partial support from the Russian Foundation for Basic Research (project r_a No. 17-44-540601) and with a material from CSBG representing USFs (Unique Scientific Facilities) "Collections of living plants indoors and outdoors" USU 440534. The English language was corrected and certified by shevchuk-editing.com.

\section{LITERATURE CITED}

Agati, G., P. Matteini, A. Goti \& M. Tattini 2007. Chloroplastlocated flavonoids can scavenge singlet oxygen. New Phytologist 174(1):77-89.

Andersen, Ø.M. \& K.R. Markham (ed.) 2006. Flavonoids: Chemistry, Biochemistry and Applications. CRC Press/Taylor \& Francis, Boca Raton. 1198 pp.

Chalas, J., C. Claise, M. Edeas, C. Messaoudi, L. Vergnes, A. Abella \& A. Lindenbaum 2001. Effect of ethyl esterification of phenolic acids on low-density lipoprotein oxidation. Biomedicine \& Pharmacotherapy 55(1):54-60.

Chalker-Scott, L. \& L.H. Fuchigami 1989. The role of phenolic compounds in plant stress responses. In: Low temperature stress physiology in crops, (P.H. Li, ed.), pp. 67-79, CRC Press Inc., Boca Raton.

Chehab, E.W., R. Kaspi, T. Savchenko, H. Rowe, F. NegreZakharov, D. Kliebenstein \& K. Dehesh 2008. Distinct roles of Jasmonates and Aldehydes in plant-defense responses. PLOS ONE 3(4): e1904.

Cheynier, V., G. Comte, K.M. Davies, V. Lattanzio \& S. Martens 2013. Plant phenolics: recent advances on their biosynthesis, genetics, and ecophysiology. Plant Physiology and Biochemistry 72:1-20.

Cilius, M., K. Ramanauskien \& V. Briedis 2013. Release of propolis phenolic acids from eemisolid formulations and their penetration into the human skin in vitro. Evidence-Based Complementary and Alternative Medicine Article ID 958717, 7 pp. Available from: https://www.hindawi.com/journals/ ecam/2013/958717/. Last accessed 26.02.2019.

Combrinck, S., G.W. Du Plooy, R.I. McCrindle \& B. M. Botha 2007. Morphology and histochemistry of the glandular trichomes of Lippia scaberrima (Verbenaceae). Annals of Botany 99:1111-1119.

Dai, G.H., M. Nicole, C. Andary, C. Martinez, E. Bresson, B. Boher, J.F. Daniel \& J.P. Geiger 1996. Flavonoids accumu- late in cell walls, middle lamellae and calloserich papillae during an incompatible interaction between Xanthomonas campestris pv. malvacearum and cotton. Physiological and Molecular Plant Pathology 49:285-306.

Dardick, C. \& P. Ronald 2006. Plant and animal pathogen recognition receptors signal through non-RD kinases. PLoS Pathogens 2, e2. Available from: https://www.ncbi. nlm.nih.gov/pmc/articles/PMC1331981/. Last accessed 26.02.2019.

David, R. \& J.P. Carde 1964. Coloration différentielle des inclusions lipidiques et terpéniques des pseudophylles du Pin maritime au moyen du réactif Nadi. Comptes rendus de l'Académie des Sciences 258:1338-1340.

English, S., W. Greenaway \& F.R. Whatley 1992. Analysis of phenolics of bud exudate of Populus tristis by GC/MS. Zeitschrift für Naturforschung 47c: 512-515.

EUCAST Disk Diffusion Method for Antimicrobial Susceptibility Testing. Version 6.0. Available from: http:// www.eucast.org/fileadmin/src/media/PDFs/EUCAST_ files/Disk_test_documents/Version_5/Manual_v_6.0_ EUCAST_Disk_Test_final.pdf. Last accessed 26.02.2019.

Evans, J.R. \& T.C. Vogelmann 2003. Profiles of ${ }^{14} \mathrm{C}$ fixation through spinach leaves in relation to light absorption and photosynthetic capacity. Plant Cell and Environment 26(4): 547-560.

Fershalova, T., E. Baikova \& A. Ushakova 2018. Application of phytoncidal plants for improvement of ecological parameters of the air of library interiors. Prospects of Development and Challenges of Modern Botany, BIO Web of Conferences 11, 00014.

Ganter, P. \& G. Jollés 1969. Histochimie normale et pathologique, vol. 1. Gauthier-Villars, Paris. 923 pp.

Glas, J.J, B.C. Schimmel, J.M. Alba, R. Escobar-Bravo, R.C. Schuurink \& M.R. Kant 2012. Plant glandular trichomes as targets for breeding or engineering of resistance to herbivores. International Journal of Molecular Sciences 13(12): 17077-17103.

Greenaway, W., J. May, T. Scaysbrook \& F.R. Whatley 1992a. Compositions of bud and leaf exudates of some Populus species compared. Zeitschrift für Naturforschung 47c, 329-334.

Greenaway, W., J. May, T. Scaysbrook \& F.R. Whatley 1992b. Analysis of phenolics of bud exudates of Populus simonii and Populus yunnanensis by GC-MS. Zeitschrift für Naturforschung 47c, 477-480.

Gu, C., C.I. Peng \& N.J. Turland 2007. Begoniaceae. In: Flora of China, vol. 13 (Clusiaceae - Araliaceae). (Z.Y. Wu, P.H. Raven \& D.Y. Hong, eds), pp. 153-207, Science Press, Beijing, and Missouri Botanical Garden Press, St. Louis.

Heinrich, G., H.W. Pfeifhofer, E. Stabentheiner \& T. Sawidis 2002. Glandular hairs of Sigesbeckia jorullensis Kunth (Asteraceae): morphology, histochemistry and composition of essential oil. Annals of Botany 89(4):459-69.

Hughes, N.M., T.C. Vogelmann \& W.K. Smith 2008. Optical effects of abaxial anthocyanin on absorption of red wavelengths by understorey species: revisiting the back-scatter hypothesis. Journal of Experimental Botany 59(12):3435-3442.

Hughes, N.M., K.L. Carpenter, T.S. Keidel, C.N. Miller, M.N. Waters \& W.K. Smith 2014. Photosynthetic costs and benefits of abaxial versus adaxial anthocyanins in Colocasia esculenta 'Mojito'. Planta 240(5):971-981.

Hwang, G.B., K.J. Heo, J.H. Yun, J.E. Lee, H.J. Lee, C.W. Nho, G.N. Bae \& J.H. Jung 2015. Antimicrobial air filters using natural 
Euscaphisjaponica nanoparticles. PLoS ONE 10(5): e0126481.

ICH Harmonised Tripartite Guideline. Validation of analytical procedures: text and methodology Q2(R1). Geneva: 2005. Available from: https://www.ich.org/fileadmin/ Public_Web_Site/ICH_Products/Guidelines/Quality/ Q2_R1/Step4/Q2_R1_Guideline.pdf. Last accessed 26.02.2019.

Jansen, M.A.K., R.A. van der Noort, A. Tan, E. Prinsen, M.L. Lagrimini \& R.N.F. Thorneley 2001. Phenol-oxidizing peroxidases contribute to the protection of plants from ultraviolet radiation stress. Plant Physiology 126:1012-1023.

Joshi, K.R., H.P. Devkota, T. Nakamura, T. Watanabe \& S. Yahara 2015. Chemical constituents and their DPPH radical scavenging activity of Nepalese crude drug Begonia picta. Records of Natural Products 9(3):446-450.

Kang, J.H., F. Shi, A.D. Jones, M.D. Marks \& G.A. Howe 2010. Distortion of trichome morphology by the hairless mutation of tomato affects leaf surface chemistry. Journal of Experimental Botany 61(4):1053-1064.

Kant, M.R., W. Jonckheere, B. Knegt, F. Lemos, J. Liu, B.C. Schimmel, C.A. Villarroel, L.M. Ataide, W. Dermauw, J.J. Glas, M. Egas, A. Janssen, T. Van Leeuwen, R.C. Schuurink, M.W. Sabelis \& J.M. Alba 2015. Mechanisms and ecological consequences of plant defence induction and suppression in herbivore communities. Annals of Botany 115(7): 1015-1051.

Karpova, E.A. \& T.D. Fershalova 2016. Dynamics of leaf pigments content of Begonia grandis Dryander subsp. grandis introduced in West Siberia (Novosibirsk). Vestnik Tomskogo Gosudarstvennogo Universiteta. Biologiya 1(33):140-158 (in Russian with English summary). [Карпова E.A., T.А. Фершамова. 2016. Аинамика содержания пигментов в Аистьях Begonia grandis Dryander subsp. grandis при интродукции в Западной Сибири (г. Новосибирск) // Вестник Томского государственного университета. Биология. № 1 (33). C. 140-158].

Karpova, E.A., T.D. Fershalova \& A.A. Petruk 2016. Flavonoids in adaptation of Begonia grandis Dryander subsp. grandis introduced in West Siberia (Novosibirsk). Journal of Stress Physiology \& Biochemistry 12(3):44-56.

Karpova E., T. Fershalova \& Yu. Yakimova 2018. Flavonoid content and antimicrobial properties of leaves of some $B e-$ gonia species. Sovremennaya nauka: aktual'nye problemy teorii $i$ praktiki. Seriya Estestvennye i tekhnicheskie nanki 1:5-10. [Kapпова Е.А., Фершалова Т.А., Якимова Ю.А. 2018. СоАержание фмавоноидов и антимикробные свойства листьев некоторых видов рода Begonia // Современная наука: актуальные проблемы теории и практики. Серия: Естественные и технические науки. № 1. С. 5-10.

Lahtinen, M., K. Lempa, J.-P. Salminen \& K. Pihlaja 2006. HPLC analysis of leaf surface flavonoids for the preliminary classification of birch species. Phytochemical Analysis 17:197-203

Li, X., D. Tian, C. Li, K. Liu, X. Li \& M. Nakata 2014. The history, culture, utilization, germplasm diversity and research advances of Begonia grandis Dry. Botanical Research $3: 117-139$

Li, Z.J., M, Liu, G. Dawuti, Q. Dou, Y. Ma, H.G. Liu \& S. Aibai 2017. Antifungal activity of gallic acid in vitro and in vivo. Phytotherapy Research 31(7):1039-1045.

McNally, D.J., K.V. Wurms, C. Labbé \& R. Bélanger 2003. Synthesis of C-glycosyl flavonoid phytoalexins as a sitespecific response to fungal penetration in cucumber. Physiological and Molecular Plant Pathology 63:293-303.
Meyberg, M., S. Krohn, B. Brümmer \& U. Kristen 1991. Ultrastructure and secretion of glandular trichomes of tobacco leaves. Flora 185:357-363.

Muravnik, L.E. 2008. The trichomes of pericarp in Juglans (Juglandaceae): scanning microscopy, fluorescent microscopy amd histochemistry. Tsitologiza 50(7):636-642 (in Russian with English summary). [Муравник $\Lambda$.Е. 2008. Трихомы перикарпия у видов Juglans (Juglandaceae): сканирующая микроскопия, фмуоресцентная микроскопия и гистохимия // Цитология. Т. 50, № 7. С. 636-642].

Muravnik, L.E. \& A.L. Shavarda 2011. Pericarp peltate trichomes in Pterocarya rhoifolia: histochemistry, ultrastructure, and chemical composition. International Journal of Plant Sciences 172(2):159-172.

Muravnik, L.E. \& A.L. Shavarda 2012. Leaf glandular trichomes in Empetrum nigrum: morphology, histochemistry, ultrastructure and secondary metabolites. Nordic Journal of Botany 30:470-481.

Muravnik, L.E., O.V. Kostina \& A.L. Shavarda 2014. Development, structure and secretion compounds of stipule colleters in Pentas lanceolata (Rubiaceae). South African Journal of Botany 93:27-36.

Muravnik, L.E., O.V. Kostina \& A.L. Shavarda 2016. Glandular trichomes of Tussilago farfara (Senecioneae, Asteraceae). Planta 244:737-752.

Nicholson, R.L. \& R. Hammerschmidt 1992. Phenolic compounds and their role in disease resistance. Annual Review of Phytopathology 30:369-389.

Nikolova, M., R. Gevrenova \& S. Ivancheva 2003. External flavonoid aglycones from Veronica chamaedrys L. (Scrophulariaceae). Acta Pharmacentica 53:145-149.

Nikolova, M. \& A. Asenov 2006. Surface flavonoid aglycones in newly studied plant species. Natural Product Research: Formerly Natural Product Letters 20(1):103-106.

Oteiza, P.I., A.G. Erlejman, S.V. Verstraeten, C.L. Keen \& C.G. Fraga 2005. Flavonoid-membrane interactions: A protective role of flavonoids at the membrane surface? Clinical \& Developmental Immunology 12(1):19-25.

Özçelik, B, I. Orhan \& G. Toker 2006. Antiviral and antimicrobial assessment of some selected flavonoids. Zeitschrift für Naturforschung 61c:632-638.

Petrussa, E., E. Braidot, M. Zancani, C. Peresson, A. Bertolini, S. Patui \& A. Vianello 2013. Plant flavonoids - biosynthesis, transport and involvement in stress responses. International Journal of Molecular Sciences 14(7):14950-14973.

Pinheiro, C.G., J.M.S. Oliveira \& B.M. Heinzmann 2018. Structural characterization of vegetative organs of the endangered Brazilian native species Hesperozygis ringens (Benth.) Epling. Anais da Academia Brasileira de Ciências 90(3): 2887-2901.

Pireyre, N. 1961. Contributions to the morphological, histological and physiological study of cystoliths. Review of Cytology and Plant Biology 23:93-320.

Shui, Y.M., Q.R. Li \& S.H. Huang 1999. Observation of leaf epidermis and its hair of begonia from Yunnan. Acta Botanica Yunnanica 21(3):309-316.

Shui, Y.M., C.I Peng \& C.Y. Wu 2002. Synopsis of the Chinese species of Begonia (Begoniaceae), with a reappraisal of sectional delimitation. Botanical Bulletin of Academia Sinica 43: $313-327$

Soares, A.S., S.P. Driscoll, E. Olmos, J. Harbinson, M.C. Arrabaça \& C.H. Foyer 2008. Adaxial/abaxial specification 
in the regulation of photosynthesis and stomatal opening with respect to light orientation and growth with $\mathrm{CO}_{2}$ enrichment in the C4 species Paspalum dilatatum. New Phytologist 177(1):186-98.

Tattini, M., E. Gravano, P. Pinelli, N. Mulinacci \& A. Romani 2000. Flavonoids accumulate in leaves and glandular trichomes of Phillyrea latifolia exposed to excess solar radiation New Phytologyst 148:69-77.

Tattini, M., P. Matteini, E. Saracini, M.L. Traversi, C. Giordano \& G. Agati 2007. Morphology and biochemistry of on-glandular trichomes in Cistus salvifolius leaves growing in extreme habitats of the Mediterranean basin. Plant Biology 9:411-419.

Teodoro, G.R., K. Ellepola, C.I. Seneviratne \& C.Y. KogaIto 2015. Potential use of phenolic acids as anti-Candida agents: A review. Frontiers in Microbiology 6:1420.

Tissier, A. 2012. Glandular trichomes: What comes after expressed sequence tags? The Plant Journal 70:51-68.

Valant-Vetschera, K.M., E. Wollenweber, R. Faure \& E. Gaydou 2003a. New exudate flavonoids of species from the Chrysanthemum complex (Asteraceae-Anthemideae). Biochemical Systematics and Ecology 31:545-548.

Valant-Vetschera, K.M., J.N. Roitman \& E. Wollenweber 2003b. Chemodiversity of exudate flavonoids in some members of the Lamiaceae. Biochemical Systematics and Eco$\log y$ 31:1279-1289.

Valant-Vetschera, K.M. \& B. Brem 2006. Chemodiversity of exudate flavonoids, as highlighted by selected publications of Eckhard Wollenweber. Natural Product Communications 1(11):921-926.

Valant-Vetschera, K.M. \& E. Wollenweber 2007. Chemodiversity of exudates flavonoids in seven tribes of Cichorioideae and Asteroideae (Asteraceae). Zeitschrift für Naturforschung 62c:155-163.

Valkama, E., J.P. Salminen, J. Koricheva \& K. Pihlaja 2003. Comparative analysis of leaf trichome structure and composition of epicuticular flavonoids in Finnish birch species. Annals of Botany 11(6):643-655.

Valkama, E., J.-P. Salminen, J. Koricheva \& K. Pihlaja 2004. Changes in leaf trichomes and epicuticular flavonoids during leaf development in three birch taxa. Annals of Botany 94(2):233-242.
Veras, H.N.H., I.J.M. dos Santos, A.C.B. dos Santos, C.N. Fernandes, E.F.F. Matias, G. de O. Leite, H.H.F. de Souza, J.G.M. da Costa \& H. D.M. Coutinho 2011. Comparative evaluation of antibiotic and antibiotic modifying activity of quercetin and isoquercetin in vitro. Current Topics in Nutraceutical Research 9(1):25-30.

Villa-Ruano, N., Y. Pacheco-Hernández, R. Cruz-Durán, E. Lozoya-Gloria \& M.G. Betancourt-Jiménez 2017. Seasonal variation in phytochemicals and nutraceutical potential of Begonia nelumbiifolia consumed in Puebla, México. Journal of Food Science and Technology 54(6):1484-1490.

Voronkova, M.S., G.I. Vysochina, T.A. Kukushkina, O.A. Mochalova \& E.A. Andriyanova 2016. A comparative research of secondary metabolites of the closely related species Bistorta elliptica and B. plumosa of Magadan region. Voprosy biologicheskoi, meditsinskoi i farmatsevticheskoi chimii 10: 15-22 (in Russian with English summary). [Воронкова M.C., Высочина Г. И., Кукушкина Т.А., Мочалова О.А., АнАриянова Е.А. 2016. Сравнительное исследование вторичных метаболитов близкородственных видов Bistorta elliptica и B. plumosa, произрастающих в Магаданской области // Вопросы биологической, медицинской и фармацевтической химии. № 10. С. 15-22].

Wagner, G. 1991. Secreting glandular trichomes: more than just hairs. Plant physiology 96:675-679.

Werker, E., U. Ravid \& E. Putievsky 1985. Structure of glandular hairs and identification of the main components of their secreted material in some species of the Labiatae. Israel Journal of Botany 34:31-45.

Wollenweber, E., K. Mann, M. Dörr, H. Fritz, J.N. Roitman \& G. Yatskievych 1995. Exudate flavonoids in three Ambrosia species. Natural Product Letters 7:109-116.

Wollenweber, E., R. Wehde, M. Dörr \& J.F. Stevens 2002. On the occurrence of exudate flavonoids in the Borage Family (Boraginaceae). Zeitschrift für Naturforschung 57c:445-448.

Wollenweber, E., M. Christ, R.H. Dunstan, J.N. Roitman \& J.F. Stevens 2005a. Exudate flavonoids in some Gnaphalieae and Inuleae (Asteraceae). Zeitschrift für Naturforschung 60c: 671-678

Wollenweber, E., M. Dörsam, M. Dörr, J.N. Roitman \& K.M. Valant-Vetschera 2005b. Chemodiversity of surface flavonoids in Solanaceae. Zeitschrift für Naturforschung 60c: $661-670$ 